\title{
The French Pox
}

\author{
Lesley Smith
}

\section{Aetiology and epidemiology}

Syphilis (also known as 'The French Pox') landed on England's shores in about 1493. The term 'French Pox' was derived from the belief that the disease originally travelled from the New World and through France before arriving in England's green and pleasant land. Controversially, it was believed to be Christopher Columbus' own ship that brought such misery but this was not suggested until several decades after the event.

Smallpox and plague exacted a much higher toll on human life and a lot more quickly than syphilis, yet it still became one of the most prolific and feared fatal diseases for over 450 years.

The causative agent for syphilis is a spirochaete bacterium, Treponema pallidum, which is carried through the mucous membranes of the mouth, anus or genitals.

The early Tudors had no understanding of bacteria or viruses. They believed, as did the ancient Greeks, in humoral medicine, whereby illness was lodged with the individual who was out of 'balance' in some way. It was also thought possible to become ill from bad smells or poisons lodged in foods. The Tudors did understand, however, that plagues came in waves. The Black Death killed $30-50 \%$ of the population. These were the massive medical dramas; lower-ranking illnesses tended not to be well recorded.

It is therefore interesting for modern-day scholars to find actual reference to both the first known cases of a disease and also some logging from notes, fairly early on, of the development and spread of the epidemic. As early as 1505 , clusters of cases began to be recorded. Twelve years after the first notes of the disease may not be considered especially rapid by modern standards but by Tudor standards this was fast. Numerous doctors were discussing cases of syphilis in the last decade of the 15th century, especially in the Italian city-states.

Somewhere, out there in the medical community, were individuals who registered the movement of the disease and the nature of the symptoms. The natural scientists of common sense were reacting and asking the right questions such as 'How?' and 'Why?'.

The reader must appreciate that in Tudor England there were no esteemed professional publications, such as this one, in which information might be shared and disseminated. Medical schools (as we know them) did not exist. A doctor or surgeon learned their profession as an apprentice to a licensed medical practitioner or, for a rich individual, there was university first to study medicine followed by an apprenticeship. The university did provide a forum for philosophy, including debate. Unfortunately, most of the content of the studies was based on the beliefs of medical philosophers who lived centuries before the birth of Christ.

It is important to distinguish between physicians and surgeons. Physicians would have been what we would generally regard as general practitioners, and would have

J Fam Plann Reprod Health Care 2006; 32(4): 265-266

Tutbury Castle, Tutbury, UK

Lesley Smith, Curator

Correspondence to: Lesley Smith, Tutbury Castle, Tutbury, Staffordshire DE13 9JF, UK. E-mail: info@tutburycastle.com been university trained. Surgeons, who were of a lower social status, would have been 'knife men'; it was the barber surgeons who would be more likely to have done an apprenticeship.

By the mid 1500s, rich and poor alike were being infected by the Pox and a wide range of names for the disease appears in the literature and doctors' notes of the period: Hot Piss, The Clap, Winchester Goose (the Bishops of Winchester held the taxation on whore houses), the French Disease, the French Embrace, the Infinite Malady and Syphilis.

Syphilis is an interesting disease to track since it seems to have gone through some changes or mutation in terms of how symptoms were presented. Indeed, the great challenge is to ascertain whether this is the disease the contemporary doctors' notes say it is! A further complicating factor is that syphilis modified its behaviour faster than any other disease ever known.

There does not seem to be (as we know it) at the beginning of the disease a small hard chancre; instead the body was rapidly covered in pus-filled lesions that seem to correspond to the secondary stage, usually appearing several weeks after the first stage comprising just a small ulcer. The secondary stage was highly infectious. There was confusion, understandably, that this might be a form of leprosy or scabies. This presentation seems to have lasted from a matter of months to just over a year before subsiding, whereupon a cure seemed apparent. In fact, the disease was usually lying dormant and would reappear some years later as tertiary syphilis. Naturally, medical practitioners thought reoccurrences represented reinfection.

All this discussion would have been of little concern to the Tudor physician. He would be convinced that sexual contact and the stars had resulted in the body's humors being thrown out of balance in a hot, dry state (Table 1). The pus-filled blisters were seen as vents for the yellow bile humor. Like bubbling porridge, the heat was so great the skin was boiling. The hot urine further convinced medical practitioners of the extreme heat and fire elements of the Pox.

God, in this governance of the stars, would also play His part in this illness as divine retribution for the "licentious and beastly disorder" of the morally degenerate. For it was very early on in the passage of the disease that poxing of the genitals could be seen and it was but a short journey to lay the blame firmly at the whorehouse doors. The Tudors regarded God as a Michelangelo figure who could stretch out His arm and move the planets about like billiard balls, with the resultant effect on air, tides and the humors of man. The astrological sign of Ares (the Greek god of war), which is hot and dry, would be seen as controlling some of the heavens when syphilis was rampant.

Table 1 The humors and their qualities ${ }^{\mathrm{a}}$

\begin{tabular}{llll}
\hline Humor & Fluid & Heat/moisture & Element \\
\hline Sanguine & Blood & Hot and moist & Air \\
Choleric & Yellow bile & Hot and dry & Fire \\
Phlegmatic & Phlegm & Cold and moist & Water \\
Melancholic & Black bile & Cold and dry & Earth \\
\hline
\end{tabular}

aSource: Sex, Society and Medieval Women by N M Heckel. 


\section{Treatment and prevention}

Doctors set about the business of trying to cure, and in some cases try and prevent, this onslaught on society.

The main treatment for syphilis in Tudor times involved the use of mercury. Mercury ointment had been used for centuries by Arabians to treat skin disorders, particularly scabies. 'Quicksilver' sales rose dramatically. Patients were rubbed in mercury ointment, drank solutions of it, inhaled it and - to really liven up a dull afternoon - they could bend over and have their genitals injected with it. The source of the latter information is an extraordinary illustration showing the treatment together with other tortuous efforts. Then heat was applied using steam baths: barrel-style with the individual's head sticking out or alternatively saunastyle rooms for mass treatment. Iatrogenic illness was typical, and so presumably was aversion therapy for visiting a whorehouse again.

Some patients were famous, such as Mary Queen of Scots' second husband, the ghastly Darnley, who was treated in Glasgow for the French Pox. There has also been much speculation about Henry VIII, but real medical evidence is slim. Even Shakespeare has been the subject of great debate as to whether he was a sufferer, virtually only on the basis that he wrote frequently and accurately about the symptoms and treatment of syphilis. The poor Bard has been accused of just about everything else too, from bisexuality to adultery. Shakespeare was a fantastic observer, which might explain his ability to write about the Pox, though I might point out he wrote about kings and fairies too!

There is a famous medical poem (usually cited as being published in 1530 , but it is thought that it was probably written several years earlier) by Giroloma Frascastoro entitled 'Syphilis sive morbus Gallicus' ('Syphilis or the French Disease'). Contagion, treatment and symptoms all appear in this fine Latin work, which tells the story of Syphilis, the shepherd who contracted the disease by offending the gods. Many believe it was Frascastoro's poem that gave the disease its name.

Steps were taken to try and prevent the disease spreading too wildly. Henry VIII closed the whorehouses in 1546 and the boy king, his son Edward, re-opened them in 1552. The opportunity to regain this source of taxation revenue must have been too tempting.

Condoms of leather and gut were used in England and the prophylactic of "hard-pissing" was well thought of.

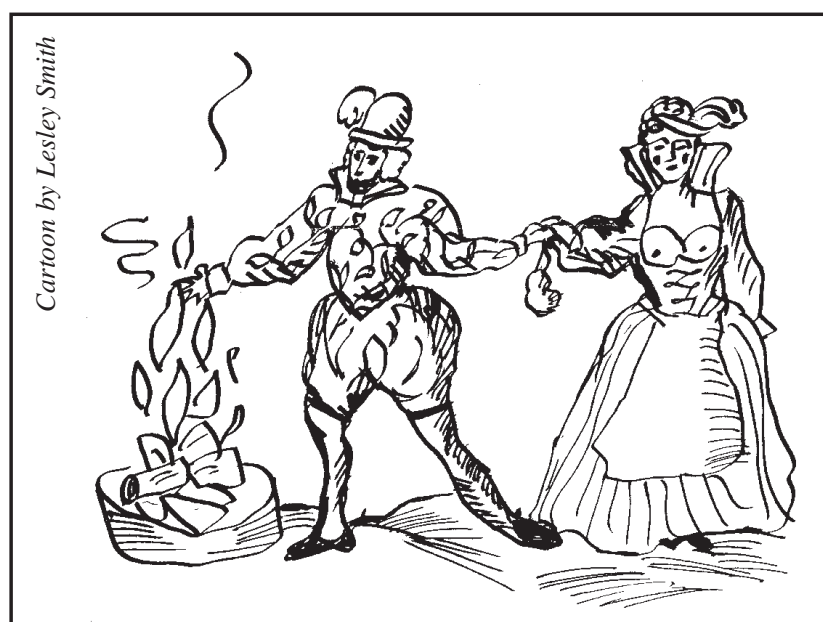

"The whorehouse client puts his hand in the fire."
"Hard-pissing" involved a prostitute having two chamber pots under the bed: one for her own use and one for her clients who immediately after ejaculation were advised to urinate as hard as they could to flush out any bodily fluids.

Even respectable, general usage household management books gave recipes for the making up of cures and salves for the French Pox. Gervase Markham, in the late 16th century, wrote in his book, The English Housewife: "Take quicksilver and kill it with fasting spittle, then take verdigris, Arabic, turpentine, oil olive, and populeon, and mix them together to one entire ointment, and anoint the sores therewith, and keep the party exceeding warm. Or otherwise, take of alum burned, of resin, frankincense, populeon, oil of roses, oil de bay, oil olive, green copperas, verdigris, white lead, mercury sublimate, of each a pretty quantity but of alum most, then beat to powder the simples that are hard, and melt your oils, and cast in your powders and stir all well together, then strain them through a cloth, and apply it warm to the sores; or else take of capon's grease that hath touched no water, the juice of rue and the fine powder of pepper, and mix them together to an ointment, and apply it round about the sores, but let it not come into the sores, and it will dry them up".

\section{Future articles}

This article only deals with the first hundred years of the onslaught of syphilis. The next few hundred years, until the antibiotic revolution of the 1940s, are equally as fascinating. The events of those centuries are the subject of another article.

Readers may be interested to note that the next article in the series will be on the subject of childbirth.

The author invites readers who would like to find out more about any of the articles in this series to write to her personally and all correspondence will be answered.

\section{Acknowledgements}

The author would like to thank the following individuals for their help and advice: Dr R Arnott, Sub-Dean of Medicine and Director of The Medical School, University of Birmingham, Birmingham, Dr G Williams, Curator of the British Museum, London and Dr R K Dart, Consultant Microbiologist.

Bibliography

1 Markham, Gervase (1568?-1637). The English Housewife. Best, Michael R (ed ) (translated from the primary source). Montreal and Kingston, Canada: McGill-Queen's University Press, 1986. A contemporary piece written to advise housewives on wide ranging topics from home medicine to cooking to brewing. The Renaissance woman's handbook.

2 Heckel NM. Sex, Society and Medieval Women, http://www.lib. rochester.edu/camelot/medsex/text.htm [Accessed 16 July 2006].

3 Leyser, Henrietta. Medieval Women. London, UK: Phoenix Press, 1995.

4 Haynes, Alan. Sex in Elizabethan England. Stroud, UK: Sutton Publishing, 1997.

5 Petrie, Hugh. The French Pox. Bristol, UK: Stuart Press, 1999.

6 Various publications available in the The Wellcome Library for the History and Understanding of Medicine, London, UK. Every doctor who enjoys the history of medicine should be a member.

\section{About the Author}

Lesley Smith is an Elizabethan historian, currently studying for the degree of MPhil in the History of Medicine at Birmingham University Medical School. She has appeared in 24 television programmes including Tony Robinson's The Worst Jobs in History, and is currently working on an eight-part 1-hour major series on the Private Lives of Women.

Lesley is well known as a public speaker, and on 23 November 2006 Lesley will be speaking at the Faculty of Family Planning and Reproductive Health Care Current Choices Conference at the Royal Society of Medicine in London. 